\title{
Inflation Dynamics in Algeria
}

\author{
Samer Mehibel*, Yacine Belarbi \\ Centre de Recherche en Economie Appliquée pour le Développement, Algeria \\ samer.mehibel@gmail.com*, belarbiyacine@yahoo.fr
}

\begin{abstract}
In thispaper, we analyze Inflation Dynamics in Algeria between 2002 and 2016. We use a Vector Auto Regressive model (VAR), impulse response functions (IRF) and variance error decomposition (VDC) to uncover possible links between public spending component sand inflation. Wetest for the sources and dynamics of inflation in Algeria by focusing on public spending, since they are expected to exert a strong influence on the aggregate demand and hence inflation. According to the results we found, inflation in Algeria is persistent; shocks are lasting longer and having impact on the future inflation path. Social transfers and equipment spending are found to be the most contributing components of public spending in explaining inflation in Algeria.
\end{abstract}

Keywords: Inflation dynamics, Inflation persistence, The Algerian economy, Demand-pull inflation

\section{Introduction}

In the first decade of this century, inflation has known a stabilized situation. In 2005, the inflation rate dropped to $1.6 \%$ after hitting an unprecedented level Algeria never experienced since its independence estimated at $0.34 \%$ in 2000. Between 2005 and 2011 inflation rate in Algeria registered a slight increase to reach $4.5 \%$ in 2011 but in 2012 a very important hike was recorded of about $11 \%$ which was explained by the increase in food prices ( +19.6 percent for fresh food) and manufactured goods prices. Higher prices were spurred by the excess liquidity resulting from the surge in current public spending and large hydrocarbon income (IMF, 2012). In 2013 inflation rate reached 4.5\% which was the rate targeted by the bank of Algeria. While it retreated in 2014 to average 2.9 percent, average year-on-year inflation exceeded the 4 percent target of the Bank of Algeria in 2015. It was partly driven by higher import price inflation, suggesting some degree of exchange rate pass-through as the dinar depreciated significantly against major currencies in 2015.In fact starting from mid-2014, inflation started accelerating again gradually to reach 6.9 percent average year-on-year by December 2016 as a consequence of a sustained rise in manufactured goods prices, which represented 55\% on average to overall inflation. In 2016, a significant fluctuation in food prices was the origin of the peak of inflation registered in July of about 8.1 percent before decreasing for a while, then increased once again toward the end of the year.

An IMF study on the causes of inflation in Algeria, IMF (2013) ${ }^{1}$ pointed out that a decrease of loans to the public sector by more than $20 \%$ in 2012 , contributed to increase the inflationary pressures, while loans growth to the private sector decreased by $10 \%$ in 2012 . The monetary authorities raised the mandatory reserve on deposits in the banking system from 9 to $11 \%$ by expanding the absorption of liquidity estimated at 250 billion AD (23\%). This study was preceded by another study, Koranchelian, (2004) found that both real and monetary factors have an impact on inflation. Inflation is associated in the long term positively with money supply and the exchange rate and negatively with income. Thus, the rising incomes of the families do not have a positive impact on the high rate of Inflation. The author suggested that the monetary authorities must continue a prudent monetary policy to cope the inflationary pressures. Ben Naceur (2012) by studying the short and the long-run determinants of inflation in Algeria for the period from 2002 to 2011 found that only non-oil GDP gap explains inflation in the short run and in the long run he found money supply and real GDP to be the most important determinants of inflation.

An important aspect of fiscal policy in Algeria is its procyclical character (Menna \& Mehibel, 2017; Chibi et al., 2014) and its impact on inflation (Menna \& Mehibel, 2017). The aspect of cyclicality has the potential of putting pressures of instability in the economy ${ }^{2}$, such as rising inflation. Among the first reasons cited by the

2“SiklikalitasKebijakanFiskal di Indonesia”, Research Note No.11/15/DKM/BRE/CR, Bank Indonesia. 
Bank of Algeria in an analytical note on inflation in Algeria (Bank of Algeria, 2013) ${ }^{3}$ and that could be among the causes of this increase in the rate of inflation that needs to be investigated, is the increase in wages of public sector jobs and the economic public sector, which had an effect on expectations of other economic agents that the potential consumers have a surplus liquidity will therefore inevitably consume it, so it will be applied on the prices of fresh goods. Since the high level of these prices plays an important role in the formation of inflationary expectations.

In this sense, government spending can have a significant cyclical influence on economies' fundamental variables, including consumption and investment. Government spending (as a ratio of GDP), after the oil windfall of the early 2000s registered an important increase starting from 1963 with 22 percent of GDP to reach 27.1 percent of GDP in 2005 before peaking at 44.6 percent of GDP in 2012. Despite some consolidation in 2013, public spending in Algeria remains one of the highest in the region, and far above the average in the other MENA oil exporters (IMF, 2014). Government spending after the oil windfall was characterized by a very expansionary fiscal policy starting from (2001-2004) investment program called the Economic Recovery Program which was followed by a series of public investment programs (2005-2009 "Complementary Plan for Growth Support" and 2010-2014). In order to face the crisis and maintain social peace, the government changed the structure of spending in favor of wages, salaries, subsidies, and transfers but as consequence fueled inflation and introduced expenditure rigidities.

The aim of this paper is twofold. Firstly, analysing inflation persistence by studying the structure of the consumer price index (CPI) and secondly, to examine the effects of fiscal spending on inflation by focusing only on the components of the public spending. To do so,the paper is organized as follows: Following this introduction we go through a relevant literature on inflation in section 2; Section 3 passes in view of the composition and the structure of the consumer price index (CPI) in Algeria; Section 4, is devoted to the econometric study of inflation persistence and through a VAR approach we try to understand which inflation component is leading the others and at the end of this section we examine the role of demand factors in explaining inflation in Algeria; We end our paper by a conclusion.

\section{Literature Review}

The main inflation determinantscan be put into three groups: (i) Demand pull inflation ;( ii) Cost push inflation and (iii) Inflation driven by inflation expectations. Their relative importance is varying from country to another and changing over time according to five main economic factors ${ }^{4}$ starting from the utilization of economic resources which determines the level of output gap and hence the demand pull inflation and on the cost push inflation side, it can be caused by the supply side shocks of major commodities like food and energy. Besides, the changes in exchange rate can affect the general price level through the "pass through effect". Finally, the other important factor is the credibility of the monetary policy and its ability to target inflation expectations about which an appropriate proxy must be chosen. The focus of most of the recent economic studies in the last century was on the relationship between inflation and unemployment (Phelps, 1967); the recent economic literature is mainly concerned about the analysis of Inflation Dynamics (Barnett et al., 2012). We define inflation dynamics as "a non transitory change in the value, trend and the continuity of inflation over time due to changes in the relative importance of the factors motivating the inflationary process" 5 .

Basher and Elsamadisy (2012) investigates the main sources the sources and transmission of inflation in GCC countries over the period 1980-2008 and suggested that inflation in trading partners, money and the nominal effective exchange rate are affecting inflation in the short run and only money is affecting inflation in the long run. Kandil and Morsy (2009) examined the determinants of inflation in GCC countries for the period between 1970 and 2007 and found that inflation in trading partners is very important in affecting inflation, while in

3Banqued'Algérie. 2013. Inflation accelerates in 2012 in the context of currency deceleration: the need to stem the inflationary phenomenon in 2013

${ }^{4}$ Davis, Joseph H. "Evolving Inflation Dynamics: Expectations and Investment Implications”, Vanguard Investment consulting \& Research, 2007.

IIt is worth mentioning that there is no common or agreed upon definition for this phenomenon, Therefore, the study attempted to draw a precise definition of the phenomenon through reviewing various studies available in this regard. 
the long run public capital spending helps easing inflationary pressures and excess demand is an important determinant in the short run. The empirical literature on the impact of fiscal policy determinants focuses on the evaluation of the macroeconomic impact of large reductions in the budget deficit, the stabilizing capability of fiscal policy variables and the dynamic effects of discretionary fiscal policy on macroeconomic variables that has recently been revived within the framework of vector auto regressions in the work of Blanchard and Perotti (2002). Our paper focuses in its last part on the relationship between fiscal policy and inflation dynamics, by analyzing whether fiscal spending contraction can really help reducing inflation in Algeria.

It is well known that the transmission of fiscal policy to inflation can be through the aggregate demand, spillovers of public wages to private sector, as well as the effect of taxes on private sector marginal costs and consumption. By using quarterly data for a sample of 17 industrial economies, Kandil (2006) studied the asymmetry in effects of monetary shocks and government spending shocks and found a negative correlation between government spending and price inflation in most countries of the sample. Similar results were found in the works of Cukierman (1992) and Becker and Mulligan (2003).An empirical application of the RugeMurcia's 1999 work on Brazilian monthly data for a period spanning from 1980 to 1989 showed that inflation and money growth rates are associated with government spending regimes. Ezirim et al. (2008) by investigating the relationship between the growth rate of public spending and the inflation rate for the United States of America, for the period 1970-2002, found a positive correlation between the two variables and also a bi-causational relationship between them. It was widely recognized that public expenditure growth can aggravate inflationary pressures in many studied cases. However, some works as in Magazzino (2011) for the case of Mediterranean countries did not find clear results of whether government spending influences prices dynamics. The first contribution of this paper is to examine the persistence of the sub components of inflation in Algeria by analyzing the structure of the consumer price index (CPI) and to determine which sub component of the consumer price index (CPI) leads the others. The second contribution is to investigate which component of government spending affect inflation and its sub components.

Composition and Structure of the Consumer Price Index (CPI): The Algerian consumer price index (CPI) is released monthly by the National Office of Statistics and is composed of a sample of 260 goods and services. Every basket is weighted basing on the 1988 National Household Consumption Survey, and the reference year is 2001. The CPI is calculated according to the Laspeyres formula.

Table1: Descriptive Statistics of the Overall Inflation Rate and the Main Subcomponents

\begin{tabular}{|l|c|c|c|c|c|c|c|}
\hline \multicolumn{1}{|c|}{$\begin{array}{l}\text { Sample: } \\
\text { Feb2002- } \\
\text { Dec2016 }\end{array}$} & Weights & $\begin{array}{c}\text { Year-on- } \\
\text { Year }\end{array}$ & $\begin{array}{c}\text { Mean (in Percent) } \\
\text { Adjusted) } \\
\text { Month-on- } \\
\text { Month }\end{array}$ & $\begin{array}{c}\text { Standard Deviation } \\
\text { Year-on- } \\
\text { Year }\end{array}$ & $\begin{array}{c}\text { (Seasonnaly } \\
\text { Adjusted) } \\
\text { Month-on- } \\
\text { Month }\end{array}$ & $\begin{array}{c}\text { Year-on- } \\
\text { Year }\end{array}$ & $\begin{array}{c}\text { (Seasonnaly } \\
\text { Adjusted) } \\
\text { Month-on- } \\
\text { Month }\end{array}$ \\
\hline Overall CPI & 1000 & $\mathbf{4 , 4}$ & $\mathbf{0 , 3}$ & $\mathbf{2 , 3}$ & $\mathbf{0 , 8}$ & $\mathbf{0 , 5}$ & $\mathbf{2 , 4}$ \\
\hline Food Prices & 430,9 & 5 & 0,4 & 4,1 & 1,8 & 0,8 & 4,5 \\
\hline $\begin{array}{l}\text { Clothing and } \\
\text { Footwear }\end{array}$ & 74,5 & 3,7 & 0,3 & 4,2 & 0,5 & 1,1 & 1,6 \\
\hline $\begin{array}{l}\text { Housing and } \\
\text { Utilities }\end{array}$ & 92,9 & 3,1 & 0,2 & 2,3 & 0,6 & 0,7 & 2,5 \\
\hline $\begin{array}{l}\text { Furnishing and } \\
\text { Household } \\
\text { Equipment }\end{array}$ & 49,6 & 2,5 & 0,2 & 1,7 & 0,5 & 0,7 & 2,2 \\
\hline Health & 62 & 3,2 & 0,3 & 1,9 & 0,5 & 0,6 & 1,8 \\
\hline $\begin{array}{l}\text { Transportation } \\
\text { \& Comunication }\end{array}$ & 158,5 & 4,7 & 0,4 & 4,5 & 1 & 1 & 2,7 \\
\hline $\begin{array}{l}\text { Recreation and } \\
\text { culture } \\
\text { Education }\end{array}$ & 45,2 & 2,1 & 0,2 & 3,7 & 1,8 & 1,8 & 9,9 \\
\hline Others & 86,4 & 5,6 & 0,4 & 5,5 & 1,1 & 1 & 2,4 \\
\hline Underlying CPI & 410,6 & 3,6 & 0,3 & 2 & 0,3 & 0,6 & 1,1 \\
\hline
\end{tabular}

Source: National Office of Statistics\& our estimates 


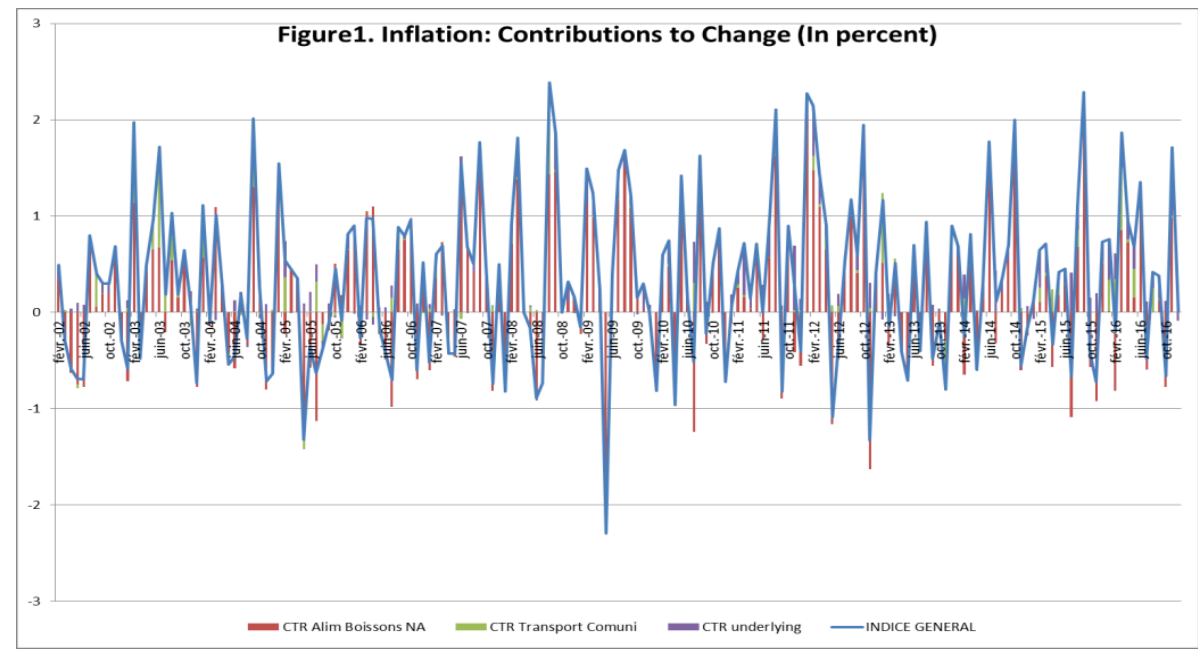

Source: National Office of Statistics \& our estimates.

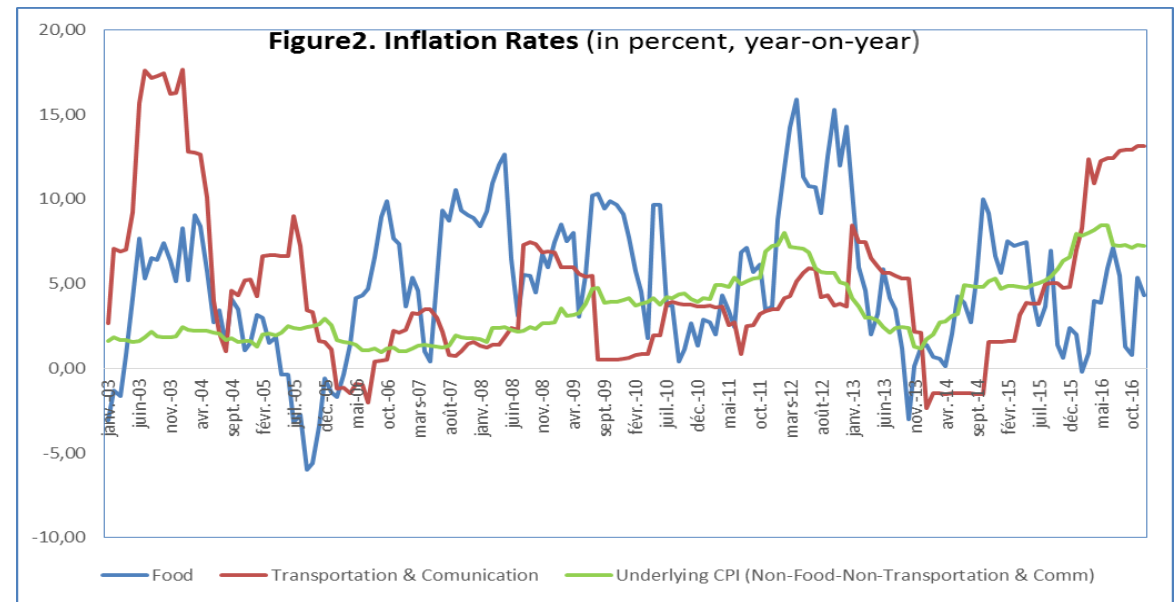

Source: National Office of Statistics \& our estimates.

In order to better understand the inflation dynamics in Algeria we split the consumer price index into its components. We distinguish hence eight sub-indices (as mentioned in the table above). According to Table1, Food and Beverages account for 43 percent of the consumption basket and are considered as a key driver of changes in inflation and of inflation volatility. Food prices constitute the largest bucket in the CPI and are more volatile than other components and its volatility is confirmed in Figure 1 and 2 comparing to underlying prices that appears to be less volatile than food prices and transportation and also the contribution of food inflation to the overall inflation is clearly apparent and we have in the second position transportation which account for 16 percent of all the basket. Underlying inflation which does not include food and transportation, shed light on the aggregate demand-driven inflationary pressures than overall inflation. The measure of underlying inflation accounts for less than half of the CPI basket which makes it a fairly weak measure

\section{Econometric Analysis}

We explore here the time series properties of inflation and its subcomponents to determine how long does it take inflation to return to its equilibrium after being hit by a shock; that is, how quickly do inflation shocks dissipate? Do shocks have a permanent impact on inflation? Which sub-components of inflation lead the others? We use in first a simple autoregressive model to capture inflation persistence (Jeffrey, 2010). At a second step we use Vector Auto-Regression (VAR) analysis to illustrate how shocks propagate and to understand which structural shocks help explaining variance in forecast errors. 
Inflation Persistence: Inflation shocks in Algeria are almost long-lived as they take merely a year and a half to dissipate. A simple autoregressive model for the overall inflation yields a coefficient of about0.58 on its first lag, which means that one third of the inflationary impact of a shock has already dissipated after one period (Table 2). In other words, if a shock increases inflation by 10 percentage points on impact, in the following quarter would be 5.8 percentage points higher, and by the fourth quarter, 89 percent of the inflationary impact of the shock would have dissipated. If we base only on expectations to determine the current inflation rate, so inflation would be expected to return to its average rate within a year and a half. Underlying inflation is less persistent than overall inflation, but even shocks to underlying inflation do not last too long. After one year only less than 8 percent of the inflationary impact of a shock would persist (Figure 3).Food inflation, however, shows the least persistence comparing to overall inflation and underlying inflation. After one year about 2 percent of the inflationary impact of a shock would persist (Figure 3). These results about food inflation are quite logical given its high volatility. Almost 64 percent of a shock dissipates each period.

Table 2: Algeria-Persistence in CPI and its Subcomponents (Seasonally adjusted, average quarter-on-quarter inflation rates)

\begin{tabular}{ccccccc}
\hline & Constant & $\mathbf{1}^{\text {st }}$ Lag & $\begin{array}{c}\text { Adjusted R- } \\
\text { Squared }\end{array}$ & $\begin{array}{c}\text { Durbin- } \\
\text { Watson }\end{array}$ & $\begin{array}{c}\text { Akaike } \\
\text { Info }\end{array}$ & $\begin{array}{c}\text { Schwartz } \\
\text { Info }\end{array}$ \\
\hline Overall & $0.436588^{* * *}$ & $0.584499^{* * *}$ & 0.337112 & 1.773372 & 1.603732 & 1.674782 \\
Prices & $(0.131684)$ & $(0.109527)$ & & & & \\
Food Prices & $\begin{array}{c}0.766301^{* * *} \\
\text { (0.222078) }\end{array}$ & $\begin{array}{c}0.341177^{* * *} \\
(0.125607)\end{array}$ & 0.100632 & 1.849764 & 3.358569 & 3.429619 \\
Underlying & $\begin{array}{c}0.451948^{* * *} \\
\text { CPI }\end{array}$ & $\begin{array}{c}0.534988^{* * *} \\
(0.132764)\end{array}$ & 0.282908 & 2.046342 & 1.842971 & 1.914021 \\
\hline
\end{tabular}

Source: Our estimates

Note: Coefficient on own lag, Standard deviation in parentheses.

*Indicates 10 percent, ${ }^{* *}$ indicates 5 percent, and ${ }^{* * *}$ indicates 1 percent significance, respectively.

In order to measure persistence we can use also the method of "Sum of Autoregressive Coefficients" or SARC first proposed with some modifications in Andrews and Chen (1994) as a better measure of single-number estimate of long-run dynamics than unit root test.

Vector Auto-Regression Analysis: In view of the results presented so far we can assume that inflation represents different properties. These findings make us conclude that different elements are pushing and pulling inflation which must be taken into consideration. That does not mean that there are no common factors, but the evidence confirms the existence of some distinct shocks to food prices as well as to underlying inflation. In the following we use a multivariate approach to model this clearly. We estimate a VAR on the quarter-on-quarter seasonally adjusted underlying (UDR) and food (ABN) inflation rates. The unit root test (Augmented Dickey-Fuller) we run gave us a confirmation that both inflation series are stationary. The selection criterion suggests using one lag in modeling (Table 3).

Table 3: VAR estimation results

\begin{tabular}{ccc}
\hline \hline & ABNSM & UDRSM \\
\hline \hline ABNSM(-1) & 0.322869 & 0.021667 \\
& $(0.12524)$ & $(0.05966)$ \\
UDRSM(-1) & {$[2.57809]$} & {$[0.36318]$} \\
& 0.338557 & 0.530608 \\
& $(0.24212)$ & $(0.11534)$ \\
& {$[1.39829]$} & {$[4.60024]$} \\
& 0.469079 & 0.430913 \\
& $(0.30606)$ & $(0.14580)$ \\
& {$[1.53263]$} & {$[2.95545]$} \\
\hline \hline
\end{tabular}


The results indicate that for the two variables each lagged variable of them is significant which means that underlying inflation is explained only by its lagged variable and food inflation is explained only by its lagged variable. For identification purposes, we say that underlying inflation is largely hit by aggregate demand shocks, while food prices, in contrast, are subject to both aggregate demand and supply shocks. These supply shocks will also affect underlying inflation through higher food prices but with a lag. This assumption is implemented through a Cholesky decomposition. Granger-causality tests suggest that there is some, albeit weak, evidence of food price inflation leading underlying inflation, supporting our identifying assumption.

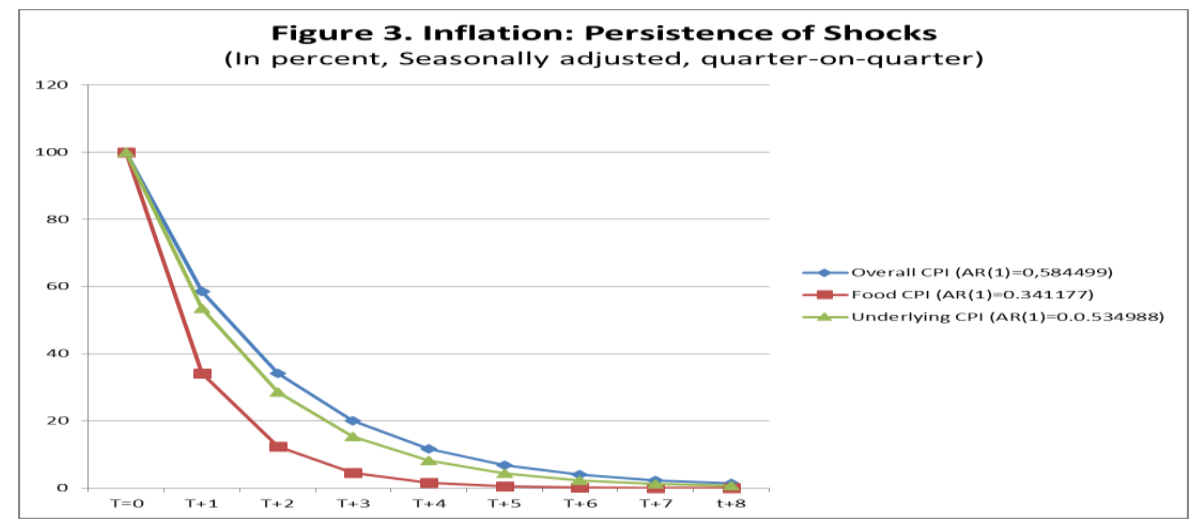

The impulse response function presented below (Figure 4) shows that a shock of food inflation lasts between 6 to 7 periods before fading and has an impact estimated atabout 0.018846 in the second period on underlying inflation and an impact of 1.264849 on itself starting from the first period. Regarding the impulse response function of underlying inflation's shock, we can observe that it lasts between 7 to 8 periods to dissipate with an impact of -0.016132 on food inflation which represents the highest levels of impact and 0.602338 on itself from the beginning.

\section{Figure 4: The Impulse Response Functions}
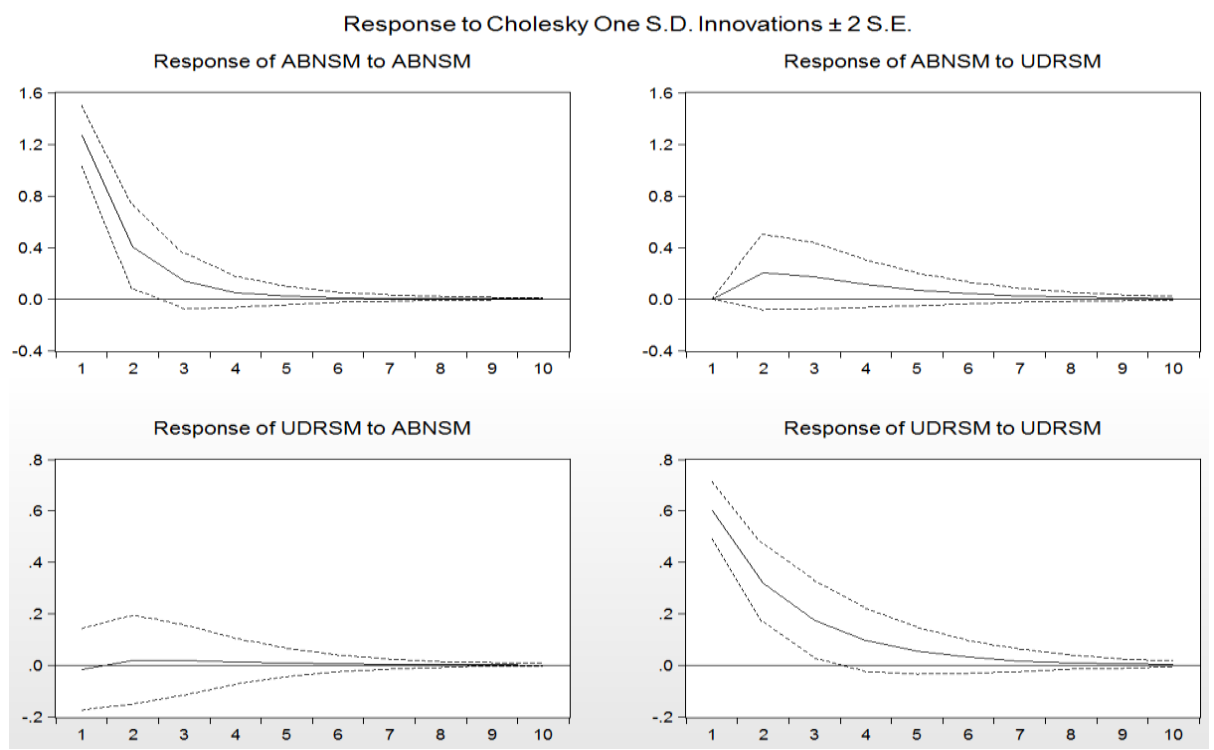
Table 4: Variance decomposition

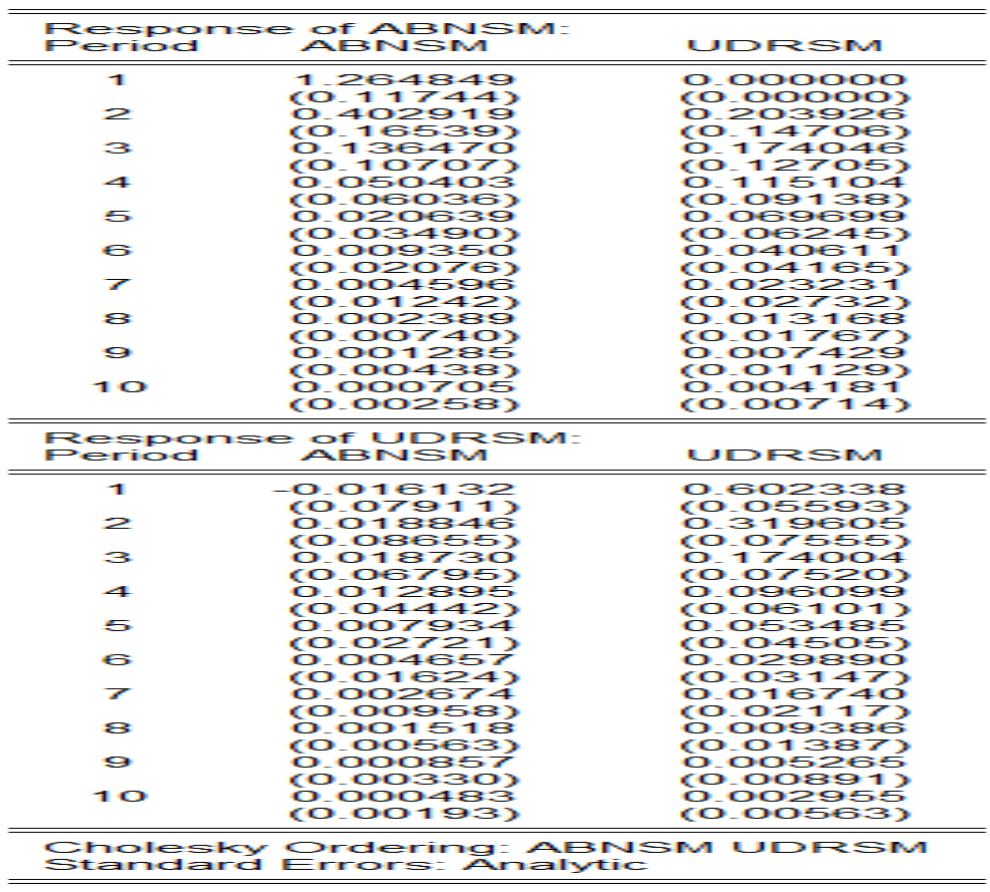

Variance decomposition (Table 4) indicates that about 74 percent of the forecast errors of food inflation can be explained by its own innovations and the 25 percent left of the forecast errors are explained by the innovations of underlying inflation. When we put it differently, we can say that the aggregate demand explains 25 percent of food prices and supply shocks explain 75 percent of food prices. On the other hand, 96 percent of the forecast errors of underlying inflation are explained by its own innovations and the 4 percent left are explained by food inflation's innovations. Economically speaking, 4 percent of the forecast errors are explained by the supply shocks and 96 percent are explained through the aggregate demand.

According to the results of impulse response function and variance decomposition we can assume with weak evidence that underlying inflation leads food inflation. This means that underlying inflation is hit by aggregate demand and it shows that supply shocks seem powerless to affect underlying inflation in return. In other words, any supply shock has no impact or the least we can say a really very low impact on food inflation even through high food prices. Aggregate demand shock affects both underlying and food inflation, with a slightly larger impact on underlying inflation (Figure 4). A one standard-deviation aggregate demand shock increases underlying inflation by about 60 percentage points in the first period and food inflation by 20 percentage points in the second period. Looking now at the supply shock side, a one-standard deviation supply shock, which by construction affects only food inflation pushes it up by 13 percentage points in the first period and increases underlying inflation by 2 percentage points in the first period which is considered as weak. All the shocks here for the two sides demand and supply dissipate after 7 or 8 periods and have no statistically significant effect afterwards.

The Role of Fiscal Spending: We explore in this subsection how government spending variations can explain inflation dynamics. Government spending has greatly increased in the last years (Figures 5, 6 and 7) because of the economic recovery programs that encourage an expansionary public spending policy from 2002 and could be expected to drive the aggregate demand and consequently inflation. We are interested here in three measures of government spending: (i) Equipment spending; (ii) Wages; (iii) Transfers. 


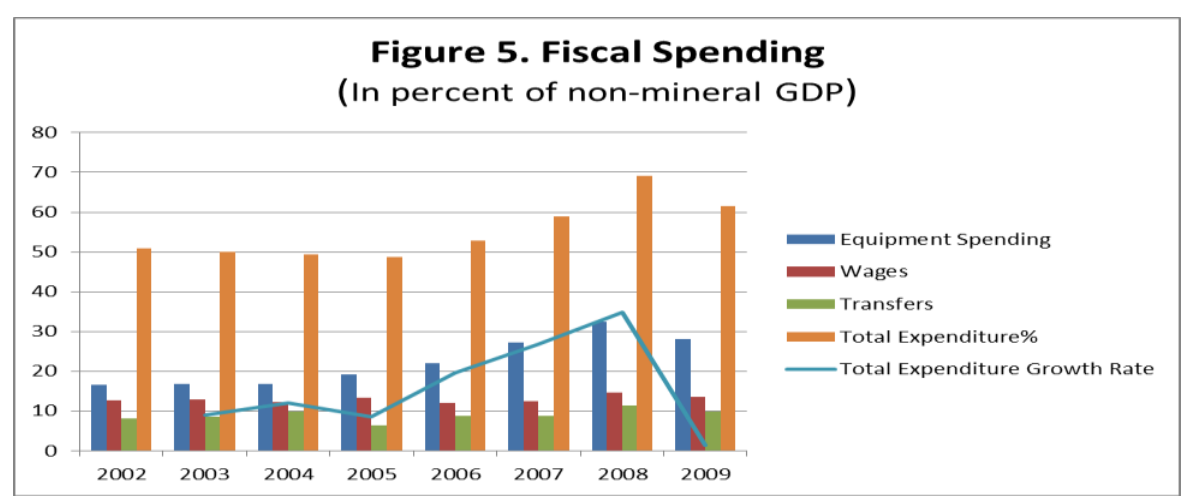

We assume that transfers and equipment spending to have a strong impact on inflation. The reason why we think so is that the country has experienced many social, political and economic major events that required the appeal of fiscal spending, some was economically justified and others not. As it is known in the last fifteen years Algeria has known a very large projects in its history since the independence, most of them were classified in the column of great public works such as the east west highway, the metro, the tramway, dams, tunnels, ports...etc and for the achievement of all of these, great financial resources were needed and fiscal spending was the only source to account on basing on high oil revenues, the problem with these projects is that many of them are now destined for public service without any return on these big investments.

Many major events have been the cause of the spectacular increase in the last decade of transfers which are mainly composed of expenditures regarding price support fund, social development fund, fund of natural calamities, subsidy interest in housing and the national fund to support youth employment. The major events we mentioned before were manifested in terms of social pressures like the uprising occurred in the early of 2011 as a consequence of the rise in food prices and that pushed the government to enlarge and increase the support of prices of goods of first necessities, also the protests regarding housing made an additional burden on the public treasury by launching several projects to satisfy the demand and calm down the social front and by supplying the fund of subsidy interest to help people buying houses at a very low interest rates. Moreover, the devices for the creation of jobs created by the government has taken a very great part of the treasury to attenuate the protests by giving the youths loans to create micro enterprises at a zero interest rate which are unfortunately in many cases not reimbursed.

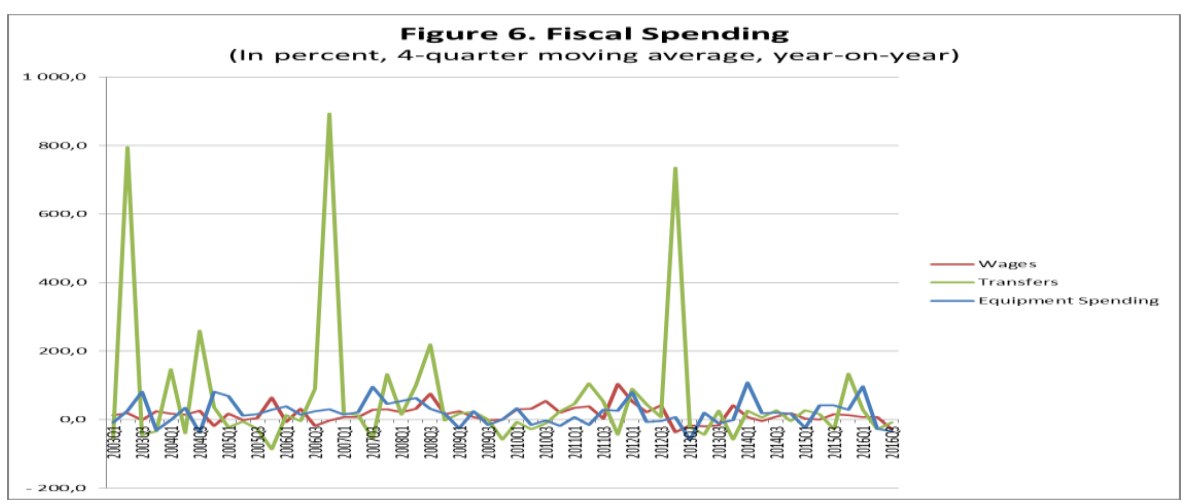

Besides, Algeria has historically been prone to many natural disasters (Floods and Earthquakes), the most known in the recent years are: the earthquake of Boumerdes and Algiers in 2003, the floods of Ghardaia in 2010 and Algiers in 2013. We have to mention here that the insurance system in Algeria is weak and the insurance culture does not exist, which means that most of the properties in Algeria are not insured making the government responsible for rebuilding and reimbursing the losses. 

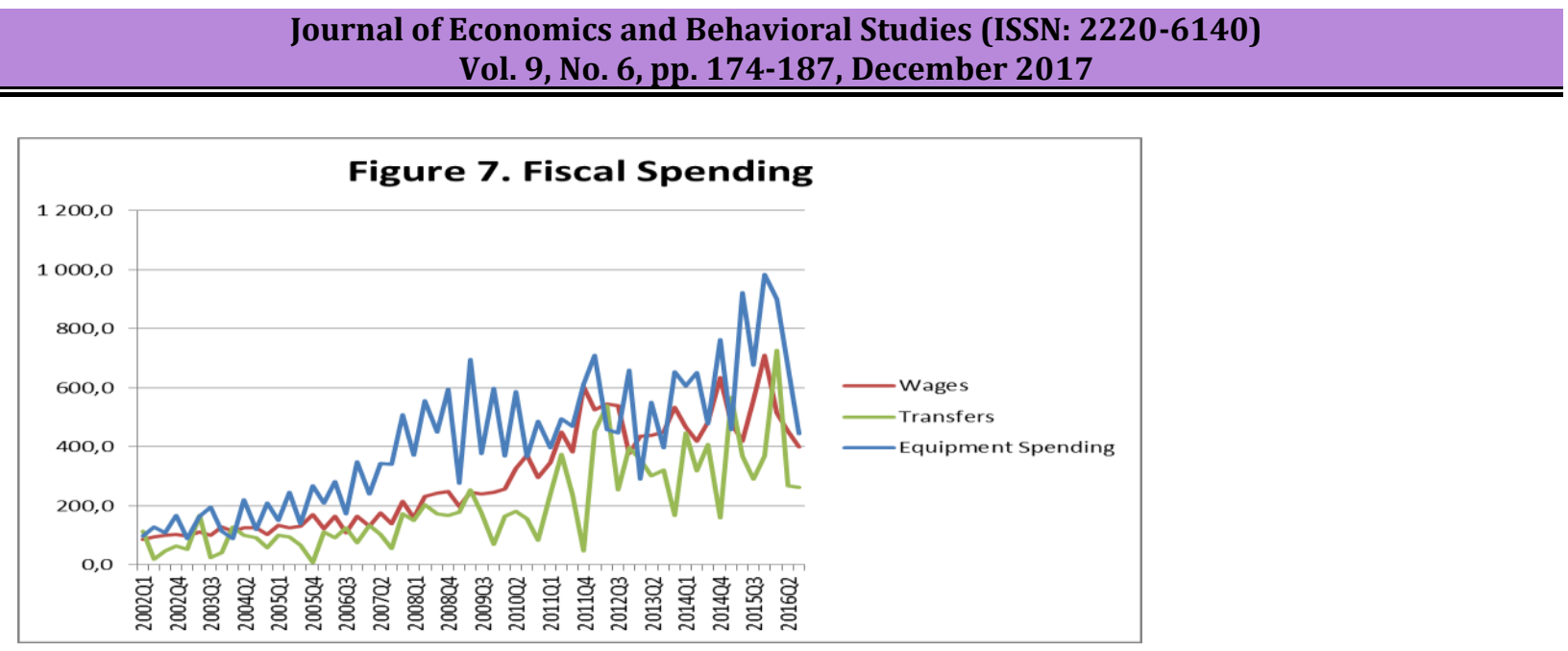

Source: Ministry of Finance and our estimate

It is obvious that transfers increase push up food inflation (Tables 6 to 10), the impact estimated at around 0.07 suggesting that 10 percent increase in transfers would increase food inflation by about 0.7 percentage points. We can notice that transfers are statistically significant in all specifications in which it is included and the parameter estimate is merely stable. Transfers are the only contributing component of government expenditure to food inflation in terms of statistical significance. As a conclusion for food inflation, transfers are statistically significant at around 5 percent level where it is specified with or without the other components. We can conclude also by observing the R-squared registered in columns 2, 4, 6 and 7 (0.513296/ $0.516035 / 0.526546 / 0.530244$ respectively) that the information contained in wage bill and equipment spending help explaining the specification but we have to say that the help is not that significant because the presence only of transfers gave us an R-squared of 0.513296. The presence of wage bill with transfers gave us an R-squared of 0.516035 while the R-squared in the presence of equipment spending with transfers is 0.526546 and when we have wage bill and equipment spending with transfers we get an R-squared equal 0.530244 which means that the component wage bill has less explanatory power for food inflation comparing to transfers and equipment spending which have both and respectively the power in explaining food inflation despite their statistical significance. However, food inflation is not persistent. Another part of the analysis regarding food inflation can be attributed to the organization of market at wholesale and retail sale level. These markets are characterized by its poor organization and its random feature especially for agricultural goods. It is not known how the prices are set, and advertisement on the goods is absent, and have less control and less application of regulations if we do not say inexistent. These factors contribute to the excessive rise of prices with the note on the presence of monopoly on the market.

On the other hand, underlying inflation presents different results comparing to food inflation and is seen to be explained by wage bill, transfers and equipment spending at a threshold of $10 \%$ (Tables5.3 \& 5.4), the impact of equipment spending is estimated at around 0.018280 indicating that a 10 percentage increase in equipment spending would increase underlying inflation by 0.1828 percentage points. The same way, a $10 \%$ increase in wage bill would increase underlying inflation by 0.28964 and a $10 \%$ increase in transfers would increase underlying inflation by 0.13757 . Most of the regressions for the case of underlying inflation indicate that two components are found to be significant at the threshold of $5 \%$. The model that was chosen to be the best model is the one which has the smallest AIC and SC where all the components are significant (regression 70).

In the overall inflation regressions it turns out that wage bill is not significant and therefore does not explain overall inflation, in all the regressions transfers is the only contribution factor in explaining overall inflation at the threshold of $10 \%$ and $5 \%$ with or without the other components of government spending. The other contributing factor in explaining overall inflation is equipment spending, but this component is significant in some regressions only especially in the regressions where the constant is absent. The best model for overall inflation is the regression 90 that gives the smallest AIC and SC and in this model the impact of transfers is 
estimated at around 0.035315 making clear that an increase of 10 percentage in transfers would increase overall inflation by 0.35315 percentage points and an increase of $10 \%$ in equipment spending would increase overall inflation by 0.30367 percentage points.

The below results (Tables 6 to 10) indicate that government spending is inflationary. However the quantitative impact is small. To look deep into the relationship, we looked at the results using lagged government spending and we found that lagged terms were always statistically significant which suggest the contemporaneous of the impact of government spending on inflation in general. We can rely on two points in order to interpret the results we got in this paper: (i) The first point is the character of fiscal policy in Algeria which is procyclical (Menna \& Mehibel, 2017; Chibi et al., 2014). (ii) The second, which goes in the same direction, about it we can find a huge literature is the problem of fiscal policy synchronization with the business cycle economy. For fiscal policy and in order to play the role of automatic stabilizer, a period of economic expansion should be faced by the government by reducing its spending or increasing its tax revenue. On the contrary, when the economy is contracting, fiscal policy should be expansionary through rising spending or reducing tax revenue. What we notice for the case of Algeria is that there is no synchronization of fiscal policy in Algeria with the business cycle, and instead of being synchronized with business cycle government spending was strongly moving with hydrocarbon revenues registering then a coefficient of correlation equal to $0.75^{6}$.

Table 5: Inflationary impact of Government Spending

\begin{tabular}{|c|c|c|c|c|c|c|c|c|c|c|c|c|c|c|c|c|c|}
\hline & \multicolumn{17}{|c|}{ Food Inflation } \\
\hline & 1 & 2 & 3 & 4 & 5 & 6 & 7 & 8 & 9 & 10 & 11 & 12 & 13 & 14 & 15 & 16 & 17 \\
\hline Constant & 0.008120 & 0.006573 & 0.006007 & 0.007062 & 0.006611 & 0.005152 & 0.005667 & 0.017761 & 0.013861 & 0.016593 & 0.014335 & 0.017304 & 0.013505 & 0.013970 & & & \\
\hline Std error & 0.002742 & 0.002535 & 0.002850 & 0.002713 & 0.002978 & 0.002796 & 0.002933 & 0.004581 & 0.004220 & 0.004657 & 0.004540 & 0.004919 & 0.004566 & 0.004844 & & & \\
\hline Pval & 0.0046 & 0.0124 & 0.0400 & 0.0121 & 0.0310 & 0.0713 & 0.0591 & 0.0003 & 0.0018 & 0.0008 & 0.0027 & 0.0009 & 0.0047 & 0.0058 & & & \\
\hline $\begin{array}{l}\text { Lagged } \\
\text { Dependant }\end{array}$ & 0.663577 & 0.639729 & 0.688345 & 0.639186 & 0.687988 & 0.662477 & 0.662715 & & & & & & & & 0.765944 & 0.701653 & 0.758840 \\
\hline Std error & 0.098044 & 0,095277 & 0.098947 & 0.095960 & 0.099398 & 0.096835 & 0.097436 & & & & & & & & 0.093462 & 0.090917 & 0.089090 \\
\hline Pval & 0.0000 & 0.0000 & 0.0000 & 0.0000 & 0.0000 & 0.0000 & 0.0000 & & & & & & & & 0.0000 & 0.0000 & 0.0000 \\
\hline Trend & & & & & & & & 0.000137 & 0.000173 & 0.000148 & 0.000169 & 0.000143 & 0.000178 & 0.000174 & 0.000141 & 0.000141 & 0.000111 \\
\hline Std error & & & & & & & & 0.000138 & 0.000130 & 0.000139 & 0.000132 & 0.000141 & 0.000133 & 0.000134 & $7.83 \mathrm{E}-05$ & $7.27 \mathrm{E}-05$ & $7.58 \mathrm{E}-05$ \\
\hline Pval & & & & & & & & 0.3260 & 0.1878 & 0.2930 & 0.2036 & 0.3159 & 0.1862 & 0.2007 & 0.0770 & 0.0589 & 0.1475 \\
\hline Dummy & & & & & & & & & & & & & & & & & \\
\hline Std error & & & & & & & & & & & & & & & & & \\
\hline Pval & & & & & & & & & & & & & & & & & \\
\hline Wage Bill & -0.037073 & & & -0.029769 & -0.042116 & & -0.034683 & -0.037920 & & & -0.023075 & -0.039206 & & -0.024148 & 0.001837 & & \\
\hline Std error & 0.057520 & & & 0.055967 & 0.057333 & & 0.055845 & 0.080691 & & & 0.076749 & 0.081557 & & 0.077609 & 0.057772 & & \\
\hline Pval & 0.5221 & & & 0.5971 & 0.4660 & & 0.5374 & 0.6404 & & & 0.7649 & 0.6328 & & 0.7570 & 0.9748 & & \\
\hline Transfers & & 0.072112 & & 0.070910 & & 0.070722 & 0.069268 & & 0.122145 & & 0.121109 & & 0.121980 & 0.120882 & & 0.088072 & \\
\hline Std error & & 0.034728 & & 0.035048 & & 0.034613 & 0.034906 & & 0.045921 & & 0.046456 & & 0.046354 & 0.046903 & & 0.035070 & \\
\hline Pval & & 0.0429 & & 0.0484 & & 0.0463 & 0.0528 & & 0.0104 & & 0.0119 & & 0.0112 & 0.0130 & & 0.0152 & \\
\hline $\begin{array}{l}\text { Equipment } \\
\text { Spending }\end{array}$ & & & 0.038184 & & 0.039808 & 0.036069 & 0.037449 & & & 0.010797 & & 0.012033 & 0.009001 & 0.009779 & & & 0.058668 \\
\hline Std error & & & 0.031408 & & 0.031628 & 0.030491 & 0.030761 & & & 0.043899 & & 0.044302 & 0.041599 & 0.042047 & & & 0.029397 \\
\hline Pval & & & 0.2297 & & 0.2140 & 0.2424 & 0.2293 & & & 0.8067 & & 0.7870 & 0.8296 & 0.8170 & & & 0.0513 \\
\hline R-squared & 0.476413 & 0.513296 & 0.487015 & 0.516035 & 0.492492 & 0.526546 & 0.530244 & 0.024355 & 0.137555 & 0.021350 & 0.139081 & 0.025764 & 0.138346 & 0.140011 & 0.423237 & 0.486701 & 0.465005 \\
\hline Observations & 55 & 55 & 55 & 55 & 55 & 55 & 55 & 55 & 55 & 55 & 55 & 55 & 55 & 55 & 55 & 55 & 55 \\
\hline AIC & -6.024632 & -6.097680 & -6.045089 & -6.066286 & -6.018786 & -6.088244 & -6.059048 & -5.356303 & -5.479631 & -5.353228 & -5.445038 & -5.321385 & -5.444185 & -5.409756 & -5.927903 & -6.044477 & -6.003078 \\
\hline SC & -5.914133 & -5.987181 & -5.934590 & -5.918953 & -5.871454 & -5.940912 & -5.874883 & -5.246813 & -5.370140 & -5.243737 & -5.299050 & -5.175398 & -5.298197 & -5.227271 & -5.817404 & -5.933977 & -5.892579 \\
\hline
\end{tabular}

6IMF Country report No : 05/50 $(2005,6)$. 


\section{Journal of Economics and Behavioral Studies (ISSN: 2220-6140)}

Vol. 9, No. 6, pp. 174-187, December 2017

Table 6: Inflationary impact of Government Spending

\begin{tabular}{|c|c|c|c|c|c|c|c|c|c|c|c|c|c|c|c|c|c|c|}
\hline & \multicolumn{18}{|c|}{ Food Inflation } \\
\hline & 18 & 19 & 20 & 21 & 22 & 23 & 24 & 25 & 26 & 27 & 28 & 29 & 30 & 31 & 32 & 33 & 34 & 35 \\
\hline Constant & & & & & & & & & & & & 0.009090 & 0.006472 & 0.006698 & 0.006729 & 0.006935 & 0.004353 & 0.004587 \\
\hline Std error & & & & & & & & & & & & 0.004225 & 0.004210 & 0.004527 & 0.004281 & 0.004572 & 0.004546 & 0.004598 \\
\hline Pval & & & & & & & & & & & & 0.0364 & 0.1306 & 0.1454 & 0.1226 & 0.1358 & 0.3430 & 0.3236 \\
\hline & & & & & & & & & & & & & & & & & & \\
\hline $\begin{array}{l}\text { Lagged } \\
\text { Dependant }\end{array}$ & 0.701203 & 0.763071 & 0.700152 & 0.703939 & 0.751866 & 0.686743 & 0.751522 & 0.687664 & 0.753310 & 0.692092 & 0.693945 & 0.667092 & 0.637033 & 0.688143 & 0.636724 & 0.688153 & 0.657392 & 0.657745 \\
\hline Std error & 0.092775 & 0.090826 & 0.088962 & 0.090730 & 0.096375 & 0.094464 & 0.093068 & 0.095431 & 0.093862 & 0.092755 & 0.093591 & 0.101058 & 0.098652 & 0.101465 & 0.099458 & 0.102113 & 0.099655 & 0.100383 \\
\hline Pval & 0.0000 & 0.0000 & 0.0000 & 0.0000 & 0.0000 & 0.0000 & 0.0000 & 0.0000 & 0.0000 & 0.0000 & 0.0000 & 0.0000 & 0.0000 & 0.0000 & 0.0000 & 0.0000 & 0.0000 & 0.0000 \\
\hline Trend & 0.000140 & 0.000115 & 0.000114 & 0.000117 & 0.000219 & 0.000201 & 0.000142 & 0.000216 & 0.000170 & 0.000148 & 0.000173 & $-6.20 \mathrm{E}-05$ & $-1.02 E-05$ & $-5.60 E-05$ & $8.29 \mathrm{E}-06$ & $-2.83 E-05$ & $1.84 \mathrm{E}-05$ & 4.17E-05 \\
\hline Std error & 7.46E-05 & 7.72E-05 & 7.27E-05 & 7.40E-05 & 0.000142 & 0.000121 & 0.000128 & 0.000135 & 0.000141 & 0.000122 & 0.000135 & 0.000189 & 0.000182 & 0.000184 & 0.000188 & 0.000191 & 0.000182 & 0.000189 \\
\hline Pval & 0.0661 & 0.1430 & 0.1222 & 0.1199 & 0.1287 & 0.1017 & 0.2694 & 0.1168 & 0.2324 & 0.2321 & 0.2046 & 0.7447 & 0.9553 & 0.7624 & 0.9649 & 0.8825 & 0.9202 & 0.8258 \\
\hline Dummy & & & & & -0.003946 & -0.003230 & -0.001615 & -0.003834 & -0.002756 & -0.001757 & -0.002888 & 0.001689 & 0.001233 & 0.002445 & 0.000316 & 0.001150 & 0.000898 & -0.000218 \\
\hline Std error & & & & & 0.005980 & 0.005120 & 0.005320 & 0.005698 & 0.005857 & 0.005098 & 0.005615 & 0.006341 & 0.005827 & 0.005931 & 0.006204 & 0.006328 & 0.005807 & 0.006186 \\
\hline Pval & & & & & 0.5123 & 0.5311 & 0.7626 & 0.5041 & 0.6400 & 0.7319 & 0.6193 & 0.7911 & 0.8332 & 0.6819 & 0.9595 & 0.8566 & 0.8777 & 0.9720 \\
\hline & & & & & & & & & & & & & & & & & & \\
\hline Wage Bill & 0.001868 & -0.018482 & & -0.015890 & -0.015936 & & & -0.015400 & -0.030385 & & -0.028013 & -0.032624 & & & -0.027851 & -0.038339 & & -0.033549 \\
\hline Std error & 0.055042 & 0.057043 & & 0.054703 & 0.064033 & & & 0.061004 & 0.062810 & & 0.060222 & 0.062314 & & & 0.060628 & 0.062214 & & 0.060480 \\
\hline Pval & 0.9731 & 0.7473 & & 0.7727 & 0.8045 & & & 0.8018 & 0.6307 & & 0.6439 & 0.6030 & & & 0.6480 & 0.5406 & & 0.5817 \\
\hline Transfers & 0.088072 & & 0.081140 & 0.080934 & & 0.087913 & & 0.087881 & & 0.081282 & 0.081003 & & 0.072387 & & 0.071713 & & 0.072402 & 0.071590 \\
\hline Std error & 0.035418 & & 0.034527 & 0.034855 & & 0.035280 & & 0.035615 & & 0.034838 & 0.035125 & & 0.036244 & & 0.036569 & & 0.036080 & 0.036372 \\
\hline Pval & 0.0163 & & 0.0228 & 0.0244 & & 0.0161 & & 0.0171 & & 0.0238 & 0.0255 & & 0.0514 & & 0.0557 & & 0.0504 & 0.0550 \\
\hline & & & & & & & & & & & & & & & & & & \\
\hline $\begin{array}{l}\text { Equipment } \\
\text { Spending }\end{array}$ & & 0.060404 & 0.051273 & 0.052784 & & & 0.057125 & & 0.058889 & 0.049582 & 0.051234 & & & 0.037869 & & 0.039411 & 0.037891 & 0.039240 \\
\hline Std error & & 0.030139 & 0.028350 & 0.029082 & & & 0.030095 & & 0.030546 & 0.029021 & 0.029471 & & & 0.032466 & & 0.032769 & 0.031507 & 0.031830 \\
\hline Pval & & 0.0505 & 0.0765 & 0.0756 & & & 0.0635 & & 0.0597 & 0.0939 & 0.0885 & & & 0.2491 & & 0.2350 & 0.2350 & 0.2238 \\
\hline R-squared & 0.486713 & 0.466126 & 0.518219 & 0.519047 & 0.428217 & 0.490752 & 0.465990 & 0.491414 & 0.468528 & 0.519383 & 0.521540 & 0.477558 & 0.514184 & 0.488829 & 0.516311 & 0.492841 & 0.528394 & 0.531461 \\
\hline Observations & 55 & 55 & 55 & 55 & 55 & 55 & 55 & 55 & 55 & 55 & 55 & 55 & 55 & 55 & 55 & 55 & 55 & 55 \\
\hline AIC & -6.007463 & -5.968139 & -6.070808 & -6.035492 & -5.899538 & -6.015364 & -5.967884 & -5.979627 & -5.935612 & -6.036191 & -6.003651 & -5.952748 & -6.025432 & -5.974557 & -5.992782 & -5.945400 & -6.018080 & -5.987569 \\
\hline sc & -5.860130 & -5.820807 & -5.923476 & -5.851326 & -5.752206 & -5.868032 & -5.820552 & -5.795461 & -5.751446 & -5.852025 & -5.782653 & -5.768583 & -5.841267 & -5.790392 & -5.771784 & -5.724402 & -5.797082 & $|-5.729737|$ \\
\hline
\end{tabular}

Source: Our estimates

Table 7: Inflationary impact of Government Spending

\begin{tabular}{|c|c|c|c|c|c|c|c|c|c|c|c|c|c|c|c|c|c|}
\hline & \multicolumn{17}{|c|}{ Underlying Inflation } \\
\hline & 36 & 37 & 38 & 39 & 40 & 41 & 42 & 43 & 44 & 45 & 46 & 47 & 48 & 49 & 50 & 51 & 52 \\
\hline Constant & -0.000245 & 0.000762 & -0.000245 & 0.000239 & -0.000589 & -0.000421 & -0.000806 & 0.003558 & 0.004312 & 0.005494 & 0.002968 & 0.004316 & 0.005031 & 0.003727 & & & \\
\hline Std error & 0.000922 & 0.000855 & 0.000922 & 0.000842 & 0.000898 & 0.000948 & 0.000922 & 0.001722 & 0.001741 & 0.001800 & 0.001794 & 0.001824 & 0.001863 & 0.001886 & & & \\
\hline Pval & 0.7913 & 0.3770 & 0.7913 & 0.7773 & 0.5150 & 0.6586 & 0.3862 & 0.0438 & 0.0165 & 0.0036 & 0.1042 & 0.0218 & 0.0094 & 0.0537 & & & \\
\hline $\begin{array}{l}\text { Lagged } \\
\text { Dependant }\end{array}$ & 1.010447 & 0.968859 & 1.010447 & 0.965931 & 1.004176 & 1.011949 & 1.005758 & & & & & & & & 0.868476 & 0.891385 & 0.923863 \\
\hline Std error & 0.049562 & 0.048759 & 0.049562 & 0.046506 & 0.047681 & 0.049737 & 0.047676 & & & & & & & & 0.058504 & 0.061713 & 0.058816 \\
\hline Pval & 0.0000 & 0.0000 & 0.0000 & 0.0000 & 0.0000 & 0.0000 & 0.0000 & & & & & & & & 0.0000 & 0.0000 & 0.0000 \\
\hline & & & & & & & & & & & & & & & & & \\
\hline Trend & & & & & & & & 0.000391 & 0.000385 & 0.000372 & 0.000396 & 0.000381 & 0.000376 & 0.000386 & $6.79 \mathrm{E}-05$ & $6.60 \mathrm{E}-05$ & $4.49 \mathrm{E}-05$ \\
\hline Std error & & & & & & & & $5.19 \mathrm{E}-05$ & $5.35 E-05$ & $5.39 \mathrm{E}-05$ & $5.20 \mathrm{E}-05$ & $5.23 \mathrm{E}-05$ & $5.41 E-05$ & $5.23 \mathrm{E}-05$ & $3.06 \mathrm{E}-05$ & $3.25 \mathrm{E}-05$ & $3.23 \mathrm{E}-05$ \\
\hline Pval & & & & & & & & 0.0000 & 0.0000 & 0.0000 & 0.0000 & 0.0000 & 0.0000 & 0.0000 & 0.0313 & 0.0480 & 0.1709 \\
\hline & & & & & & & & & & & & & & & & & \\
\hline Dummy & & & & & & & & & & & & & & & & & \\
\hline Std error & & & & & & & & & & & & & & & & & \\
\hline Pval & & & & & & & & & & & & & & & & & \\
\hline & & & & & & & & & & & & & & & & & \\
\hline Wage Bill & 0.034326 & & & 0.035250 & 0.031507 & & 0.032430 & 0.062885 & & & 0.065445 & 0.065017 & & 0.067677 & 0.037725 & & \\
\hline Std error & 0.014241 & & & 0.014275 & 0.013705 & & 0.013726 & 0.030331 & & & 0.030330 & 0.030245 & & 0.030223 & 0.013251 & & \\
\hline Pval & 0.0196 & & & 0.0170 & 0.0257 & & 0.0222 & 0.0431 & & & 0.0357 & 0.0363 & & 0.0296 & 0.0063 & & \\
\hline & & & & & & & & & & & & & & & & & \\
\hline Transfers & & 0.007342 & & 0.008775 & & 0.007451 & 0.008761 & & 0.017940 & & 0.020880 & & 0.018272 & 0.021352 & & 0.010528 & \\
\hline Std error & & 0.009284 & & 0.008871 & & 0.008859 & 0.008497 & & 0.018940 & & 0.018358 & & 0.018917 & 0.018265 & & 0.008723 & \\
\hline Pval & & 0.4327 & & 0.3273 & & 0.4043 & 0.3076 & & 0.3479 & & 0.2607 & & 0.3386 & 0.2480 & & 0.2330 & \\
\hline $\begin{array}{l}\text { Equipment } \\
\text { Spending }\end{array}$ & & & 0.020170 & & 0.018571 & 0.020204 & 0.018565 & & & -0.017891 & & -0.019942 & -0.018160 & -0.020340 & & & 0.016587 \\
\hline Std error & & & 0.008218 & & 0.007924 & 0.008242 & 0.007919 & & & 0.016963 & & 0.016429 & 0.016976 & 0.016374 & & & 0.007112 \\
\hline Pval & & & 0.0176 & & 0.0231 & 0.0178 & 0.0232 & & & 0.2964 & & 0.2304 & 0.2898 & 0.2200 & & & 0.0237 \\
\hline & & & & & & & & & & & & & & & & & \\
\hline R-squared & \begin{tabular}{|l|}
0.896047 \\
\end{tabular} & 0.885608 & 0.896436 & 0.898043 & 0.906336 & 0.897881 & 0.908325 & 0.529865 & 0.499635 & 0.501663 & 0.541494 & 0.543065 & 0.510616 & 0.555221 & 0.904577 & 0.892484 & 0.900072 \\
\hline \begin{tabular}{|l|} 
Observations \\
\end{tabular} & 55 & 55 & 55 & 55 & 55 & 55 & 55 & 55 & 55 & 55 & 55 & 55 & 55 & 55 & 55 & 55 & 55 \\
\hline AIC & \begin{tabular}{|l|}
-8.817056 \\
\end{tabular} & -8.721360 & -8.820806 & -8.799400 & -8.884244 & -8.797817 & -8.868668 & -7.313201 & -7.250882 & -7.254944 & $\begin{array}{l}-7.301884 \\
\end{array}$ & -7.305316 & $\begin{array}{l}-7.236710 \\
\end{array}$ & -7.295916 & -8.902676 & $5-8.783352$ & -8.856547 \\
\hline sc & -8.706557 & -8.610861 & -8.710307 & -8.652068 & -8.736912 & -8.650484 & -8.684502 & -7.203710 & -7.141392 & -7.145453 & -7.155896 & -7.159328 & -7.090722 & -7.113431 & -8.792177 & -8.672853 & -8.746048 \\
\hline
\end{tabular}

Source: Our estimates 
Journal of Economics and Behavioral Studies (ISSN: 2220-6140)

Vol. 9, No. 6, pp. 174-187, December 2017

Table 8: Inflationary impact of Government Spending

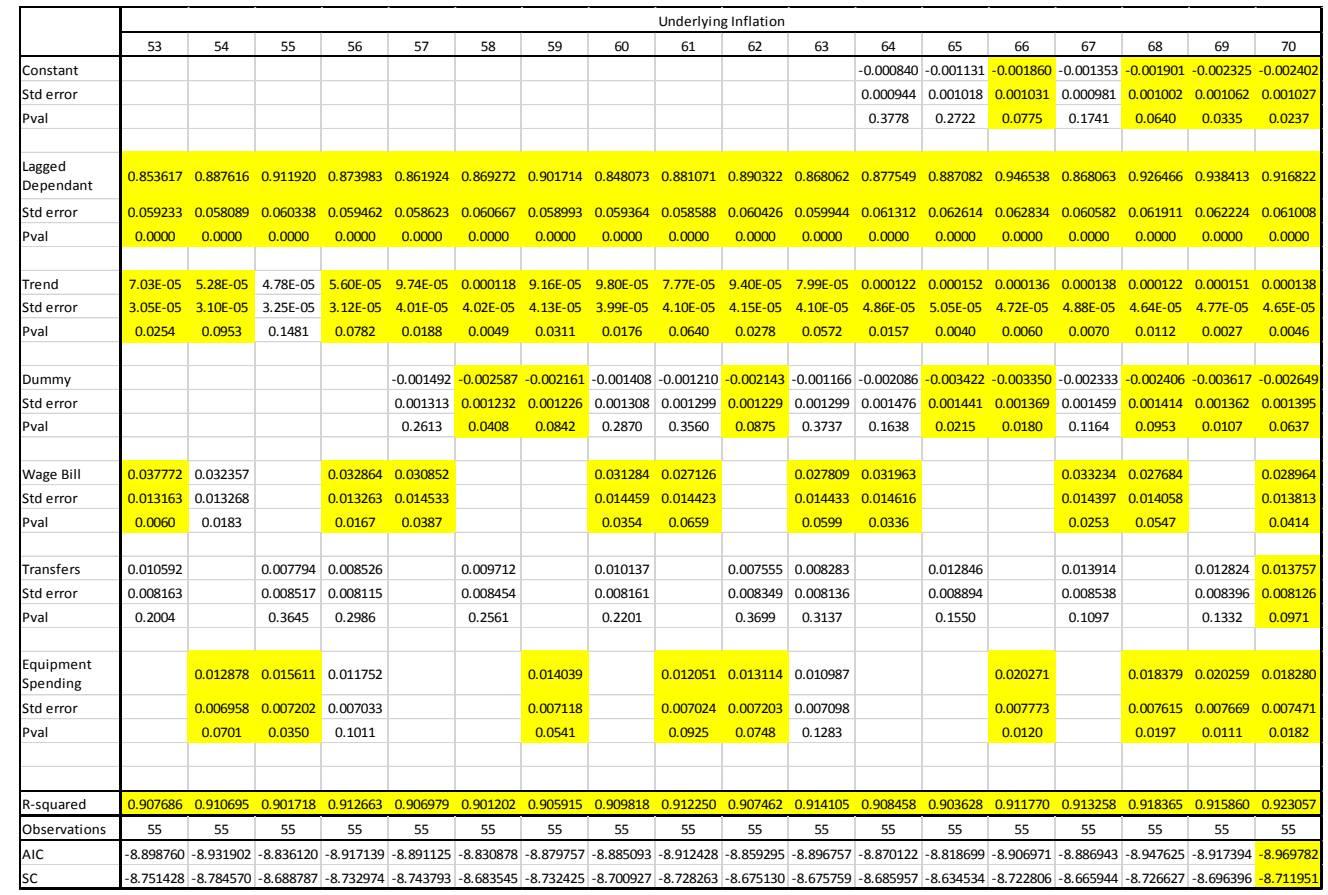

Source: Our estimates

Table 9: Inflationary impact of Government Spending

\begin{tabular}{|c|c|c|c|c|c|c|c|c|c|c|c|c|c|c|c|c|c|}
\hline & \multicolumn{17}{|c|}{ Overall Inflation } \\
\hline & 71 & 72 & 73 & 74 & 75 & 76 & 77 & 78 & 79 & 80 & 81 & 82 & 83 & 84 & 85 & 86 & 87 \\
\hline Constant & 0.004932 & 0.004367 & 0.003284 & 0.004451 & 0.003439 & 0.002932 & 0.003045 & 0.013642 & 0.012056 & 0.014165 & 0.012052 & 0.014255 & 0.012734 & 0.012694 & & & \\
\hline Std error & 0.001848 & 0.001751 & 0.002044 & 0.001838 & 0.002104 & 0.002019 & 0.002082 & 0.002538 & 0.002381 & 0.002565 & 0.002564 & 0.002715 & 0.002564 & 0.002723 & & & \\
\hline Pval & 0.0102 & 0.0159 & 0.1143 & 0.0191 & 0.1084 & 0.1526 & 0.1500 & 0.0000 & 0.0000 & 0.0000 & 0.0000 & 0.0000 & 0.0000 & 0.0000 & & & \\
\hline \begin{tabular}{|l} 
Lagged \\
Dependant
\end{tabular} & 0.760359 & 0.750133 & 0.809256 & 0.749768 & 0.809122 & 0.796535 & 0.796576 & & & & & & & & 0.853954 & 0.809104 & 0.858709 \\
\hline Std error & 0.088120 & 0.085919 & 0.092773 & 0.086777 & 0.093570 & 0.091455 & 0.092318 & & & & & & & & 0.077004 & 0.075543 & 0.071829 \\
\hline Pval & 0.0000 & 0.0000 & 0.0000 & 0.0000 & 0.0000 & 0.0000 & 0.0000 & & & & & & & & 0.0000 & 0.0000 & 0.0000 \\
\hline Trend & & & & & & & & 0.000175 & 0.000190 & 0.000167 & 0.000190 & 0.000167 & 0.000181 & 0.000181 & $8.59 \mathrm{E}-05$ & $9.51 \mathrm{E}-05$ & \\
\hline Std error & & & & & & & & 7.65E-05 & $7.32 E-05$ & $7.68 \mathrm{E}-05$ & 7.43E-05 & $7.78 E-05$ & $7.45 E-05$ & $7.55 E-05$ & $4.84 E-05$ & 4.63E-05 & $4.68 \mathrm{E}-05$ \\
\hline Pval & & & & & & & & 0.0264 & 0.0124 & 0.0338 & 0.0136 & 0.0369 & 0.0186 & 0.0200 & 0.0818 & 0.0450 & 0.1587 \\
\hline & & & & & & & & & & & & & & & & & \\
\hline Dummy & & & & & & & & & & & & & & & & & \\
\hline Std error & & & & & & & & & & & & & & & & & \\
\hline Pval & & & & & & & & & & & & & & & & & \\
\hline & & & & & & & & & & & & & & & & & \\
\hline Wage Bill & -0.007977 & & & -0.004834 & -0.010733 & & -0.007567 & -0.006685 & & & 0.000204 & -0.004960 & & 0.002092 & 0.009787 & & \\
\hline Std error & 0.029304 & & & 0.028842 & 0.029065 & & 0.028643 & 0.044694 & & & 0.043347 & 0.045014 & & 0.043625 & 0.029310 & & \\
\hline Pval & 0.7866 & & & 0.8676 & 0.7135 & & 0.7927 & 0.8817 & & & 0.9963 & 0.9127 & & 0.9620 & 0.7398 & & \\
\hline & & & & & & & & & & & & & & & & & \\
\hline Transfers & & 0.030595 & & 0.030401 & & 0.029671 & 0.029356 & & 0.056194 & & 0.056203 & & 0.056507 & 0.056602 & & 0.039900 & \\
\hline Std error & & 0.017752 & & 0.017961 & & 0.017604 & 0.017810 & & 0.025912 & & 0.026237 & & 0.026032 & 0.026365 & & 0.017944 & \\
\hline Pval & & 0.0909 & & 0.0967 & & 0.0981 & 0.1057 & & 0.0347 & & 0.0370 & & 0.0346 & 0.0367 & & 0.0306 & \\
\hline $\begin{array}{l}\text { Equipment } \\
\text { Spending }\end{array}$ & & & 0.023855 & & 0.024266 & 0.022811 & 0.023112 & & & -0.016300 & & -0.016143 & -0.017131 & -0.017199 & & & 0.033923 \\
\hline Std error & & & 0.016692 & & 0.016872 & 0.016411 & 0.016605 & & & 0.024178 & & 0.024452 & 0.023361 & 0.023635 & & & 0.014595 \\
\hline Pval & & & 0.1591 & & 0.1566 & 0.1707 & 0.1702 & & & 0.5032 & & 0.5121 & 0.4667 & 0.4702 & & & 0.0241 \\
\hline & & & & & & & & & & & & & & & & & \\
\hline R-squared & \begin{tabular}{|l|l|}
0.594387 \\
\end{tabular} & 0.616154 & 0.609438 & 0.616370 & 0.610500 & 0.630435 & 0.630961 & 0.093281 & 0.168126 & 0.100750 & 0.168126 & 0.100964 & 0.176806 & 0.176844 & 0.564659 & 0.602267 & 0.605496 \\
\hline Observations & 55 & 55 & 55 & 55 & 55 & 55 & 55 & 55 & 55 & 55 & 55 & 55 & 55 & 55 & 55 & 55 & 55 \\
\hline AIC & -7.373963 & -7.429123 & -7.411777 & -7.392647 & \begin{tabular}{|l|}
-7.377463 \\
\end{tabular} & -7.430001 & -7.394387 & -6.537891 & -6.624043 & -6.546163 & -6.587680 & -6.510037 & -6.598168 & -6.561851 & -7.303233 & -7.393583 & -7.401734 \\
\hline sc & -7.263464 & -7.318624 & -7.301277 & -7.245315 & -7.230131 & -7.282668 & -7.210222 & -6.428400 & -6.514552 & -6.436672 & -6.441692 & -6.364050 & -6.452180 & -6.379366 & -7.192734 & -7.283084 & -7.291235 \\
\hline
\end{tabular}

Source: Our estimates 


\section{Table 10: Inflationary impact of Government Spending}

\begin{tabular}{|c|c|c|c|c|c|c|c|c|c|c|c|c|c|c|c|c|c|c|}
\hline & \multicolumn{18}{|c|}{ Overall Inflation } \\
\hline & 88 & 89 & 90 & 91 & 92 & 93 & 94 & 95 & 96 & 97 & 98 & 99 & 100 & 101 & 102 & 103 & 104 & 105 \\
\hline Constant & & & & & & & & & & & & 0.004564 & 0.003494 & 0.002676 & 0.003505 & 0.002702 & 0.001668 & 0.001691 \\
\hline Std error & & & & & 2,23 & & & & & & & 0.002394 & 0.002378 & 0.002661 & 0.002415 & 0.002689 & 0.002659 & 0.002689 \\
\hline Pval & & & & & & & & & & & & 0.0625 & 0.1481 & 0.3197 & 0.1531 & 0.3200 & 0.5334 & 0.5326 \\
\hline & & & & & & & & & & & & & & & & & & \\
\hline $\begin{array}{l}\text { Dependant } \\
\text { Dend }\end{array}$ & 0.803201 & 0.859913 & 0.814509 & 0.814475 & 0.844053 & 0.794525 & 0.852288 & 0.793749 & 0.853947 & 0.807033 & 0.808275 & 0.743379 & 0.724596 & 0.790559 & 0.724715 & 0.791902 & 0.771576 & 0.772582 \\
\hline Std error & 0.077689 & 0.074074 & 0.073108 & 0.075464 & 0.079191 & 0.078559 & 0.075339 & 0.079713 & 0.076451 & 0.076539 & 0.077755 & 0.093526 & 0.091082 & 0.097187 & 0.092063 & 0.098268 & 0.095532 & 0.096674 \\
\hline Pval & 0.0000 & 0.0000 & 0.0000 & 0.0000 & 0.0000 & 0.0000 & 0.0000 & 0.0000 & 0.0000 & 0.0000 & 0.0000 & 0.0000 & 0.0000 & 0.0000 & 0.0000 & 0.0000 & 0.0000 & 0.0000 \\
\hline Trend & $9.41 E-05$ & $6.70 \mathrm{E}-05$ & 7.63E-05 & 7.63E-05 & 0.000123 & 0.000133 & $8.39 \mathrm{E}-05$ & 0.000130 & $8.93 E-05$ & $9.58 \mathrm{E}-05$ & 9.93E-05 & 1.19E-05 & $4.26 \mathrm{E}-05$ & $2.61 \mathrm{E}-05$ & $4.35 \mathrm{E}-05$ & 3.18E-05 & 5.89E-05 & $6.27 E-05$ \\
\hline Std error & 4.68E-05 & $4.72 \mathrm{E}-05$ & 4.56E-05 & 4.61E-05 & $7.83 E-05$ & $6.99 \mathrm{E}-05$ & $7.22 \mathrm{E}-05$ & $7.55 E-05$ & $7.70 \mathrm{E}-05$ & 7.04E-05 & $7.50 \mathrm{E}-05$ & $9.60 \mathrm{E}-05$ & $9.24 \mathrm{E}-05$ & 9.23E-05 & 9.55E-05 & 9.59E-05 & $9.20 \mathrm{E}-05$ & 9.53E-05 \\
\hline Pval & 0.0496 & 0.1624 & 0.1007 & 0.1043 & 0.1224 & 0.0635 & 0.2507 & 0.0915 & 0.2518 & 0.1798 & 0.1913 & 0.9018 & 0.6466 & 0.7788 & 0.6507 & 0.7416 & 0.5250 & 0.5140 \\
\hline Dummy & & & & & -0.001817 & -0.001879 & -0.000828 & -0.001758 & -0.001074 & -0.000941 & -0.001106 & 0.000811 & 0.000296 & 0.000575 & 0.000250 & 0.000299 & $-5.94 E-05$ & -0.000245 \\
\hline Std error & & & & & 0.002999 & 0.002611 & 0.002654 & 0.002891 & 0.002909 & 0.002578 & 0.002826 & 0.003231 & 0.002975 & 0.002998 & 0.003176 & 0.003214 & 0.002950 & 0.003157 \\
\hline Pval & & & & & 0.5474 & 0.4751 & 0.7564 & 0.5459 & 0.7137 & 0.7165 & 0.6972 & 0.8030 & 0.9212 & 0.8488 & 0.9375 & 0.9263 & 0.9840 & 0.9384 \\
\hline & & & & & & & & & & & & & & & & & & \\
\hline Wage Bill & 0.010947 & -0.002301 & & $6.21 E-05$ & 0.001762 & & & 0.003177 & -0.006814 & & -0.004585 & -0.003866 & & & -0.001379 & -0.008033 & & -0.005501 \\
\hline Std error & 0.028257 & 0.028673 & & 0.027878 & 0.032332 & & & 0.031174 & 0.031402 & & 0.030525 & 0.031651 & & & 0.030987 & 0.031423 & & 0.030753 \\
\hline Pval & 0.7001 & 0.9364 & & 0.9982 & 0.9568 & & & 0.9193 & 0.8291 & & 0.8812 & 0.9033 & & & 0.9647 & 0.7993 & & 0.8588 \\
\hline Transfers & 0.040030 & & 0.035315 & 0.035317 & & 0.039889 & & 0.039928 & & 0.035457 & 0.035358 & & 0.033383 & & 0.033346 & & 0.033089 & 0.032938 \\
\hline Std error & 0.018098 & & 0.017488 & 0.017682 & & 0.018029 & & 0.018214 & & 0.017646 & 0.017837 & & 0.018365 & & 0.018574 & & 0.018153 & 0.018358 \\
\hline Pval & 0.0316 & & 0.0488 & 0.0514 & & 0.0315 & & 0.0331 & & 0.0500 & 0.0532 & & 0.0752 & & 0.0789 & & 0.0746 & 0.0792 \\
\hline $\begin{array}{l}\text { Equipment } \\
\text { Spending }\end{array}$ & & 0.034146 & 0.030367 & 0.030361 & & & 0.033083 & & 0.033493 & 0.029397 & 0.029684 & & & 0.024841 & & 0.025243 & 0.024506 & 0.024782 \\
\hline Std error & & 0.014999 & 0.014283 & 0.014692 & & & 0.014970 & & 0.015233 & 0.014651 & 0.014921 & & & 0.017067 & & 0.017304 & 0.016677 & 0.016919 \\
\hline Pval & & 0.0271 & 0.0385 & 0.0441 & & & 0.0317 & & 0.0326 & 0.0503 & 0.0524 & & & 0.1519 & & 0.1511 & 0.1483 & 0.1496 \\
\hline & & & & & & & & & & & & & & & & & & \\
\hline R-squared & 0.603458 & 0.605547 & 0.635245 & 0.635245 & 0.567831 & 0.606346 & 0.606262 & 0.606429 & 0.606640 & 0.636235 & 0.636406 & 0.597663 & 0.622964 & 0.614219 & 0.622979 & 0.614743 & 0.639193 & 0.639439 \\
\hline Observations & 55 & 55 & 55 & 55 & 55 & 55 & 55 & 55 & 55 & 55 & 55 & 55 & 55 & 55 & 55 & 55 & 55 & 55 \\
\hline AIC & -7.359544 & -7.364826 & -7.443101 & -7.406064 & -7.273510 & -7.366853 & -7.366641 & -7.330028 & -7.330564 & -7.408782 & -7.372215 & \begin{tabular}{|c|}
-7.307999 \\
\end{tabular} & -7.372948 & -7.350018 & -7.335952 & -7.314342 & -7.379910 & -7.343553 \\
\hline sc & -7.212211 & -7.217493 & -7.295769 & -7.221899 & -7.126178 & -7.219521 & -7.219309 & -7.145863 & -7.146399 & -7.224617 & -7.151216 & -7.123833 & -7.188783 & -7.165853 & -7.114954 & -7.093344 & -7.158911 & -7.08572 \\
\hline
\end{tabular}

Source: Our estimates

Wage bill has no effect on overall inflation even that wages in Algeria has remarkably increased in the last years as a response by the government to social movements protesting the rise of prices. However, we find that wage bill does have an effect on food and underlying inflation.

\section{Conclusion}

The existing literature on the effect of public spending or the effect of fiscal policy can be divided into two groups: the demand side and the supply side, in this paper we have focused on the demand side of the fiscal policy effects. In other word, the transmission of public spending to inflation through aggregate demand. The regressions of food inflation, underlying inflation and overall inflation gave us proof of the significant role of government expenditure especially transfers and equipment spending in explaining the variations in inflation. Indeed, our empirical results suggest that government spending shocks have positive effect on inflation and consequently yield significant effects on the aggregate demand.

It was expected that in the long run, government spending on infrastructure can improve the distribution of goods and services and help reducing the cost of production, thereby contributing to reduce inflation. In the short run, we found a positive effect of a positive equipment spending shock on inflation; this can be explained by the possibility of greater multiplier effect of government spending on investment especially on infrastructures than routine expenditure. The estimations through the VAR approach suggest the existence of evidence pointing that underlying inflation leads food inflation and the study of the persistence indicated that shocks of food inflation are less persistent than shocks of underlying inflation.

\section{References}

Andrews, D. \& Chen, H. (1994). Approximately median-unbiased estimation of autoregressive models. Journal of Business and Economic Statistics, 12, 187-204.

Barnett, S., Bersch, J. \& Ojima, Y. (2012). Inflation Dynamics in Mongolia: Understanding the Roller Coaster, International Monetary Fund, July 2012. 
Basher, S. A. \& Elsamadisy, E. M. (2012). Country Heterogeneity and Long-run Determinants of Inflation in the Gulf Arab States. OPEC Energy Review, 36(2), 170-203.

Becker, G. S. \& Mulligan, C. B. (2003). Deadweight Costs and the Size of Government. Journal of Law and Economics, 46(2), 293-340.

Ben Naceur, S. (2012). Understanding Inflation in Algeria. Selected issues and Statistical Appendix, IMF Country Report 13/48, (Washington: International Monetary Fund).

Blanchard, O. J. \& Perotti, R. (2002). An Empirical Characterization of the Dynamic Effects of Changes in Government Spending and Taxes on Output. The Quarterly Journal of Economics, 117(4), 1329-1368.

Chibi, A., Benbouziane, M. \& Ahmed, C. S. (2014). The impact of Fiscal Policy on Economic Activity over the Business Cycle: An Empirical Investigation in the Case of Algeria. ERF Working Paper No.854.

Cukierman, A. (1992). Central Bank Strategy, Credibility and Independence, Theory and Evidence. The MIT Press, Cambridge, MA.

Davis, J. (2007). Evolving Inflation Dynamics: Expectations and Investment Implications, Vanguard Investment consulting \& Research.

Ezirim, C. B., Muoghalu, M. I. \& Elike, U. (2008). Inflation versus public expenditure growth in the US: An empirical investigation. North American Journal of Finance and Banking Research, 2(2), 26-40.

Jeffrey, C. F. (2010). Inflation Persistence. Handbook of Monetary Economics, 3, 423-486.

Kandil, M. (2006). The growth of government spending and the money supply: Evidence and implications within and across industrial countries. Journal of Economic Studies, 33(6), 406-436.

Kandil, M. \& Morsy, H. (2009). Determinants of Inflation in GCC, IMF Working Paper 09/82. (Washington: International Monetary Fund).

Koranchelian, T. (2004). Determinants of Inflation in Algeria. Selected issues and Statistical Appendix, IMF Country Report 04/31, (Washington: International Monetary Fund).

Magazzino, C. (2011). The nexus between public expenditure and inflation in the Mediterranean countries. MPRA Paper No. 28493.

Menna, K. \& Samer, M. (2017). A Decade of the Algerian Economy: Is It Really Lost? Réformes Economiques et Intégration en Economie Mondiale, $\mathrm{N}^{\circ}$ 23/2017, ISSN: 7201-1112.

Phelps, E. S. (1967). Phillips Curves, Expectations of Inflation and Optimal Unemployment over Time. Economica, 34, 254-281.

La persistance de l'inflation dans la zone euro, Perspectives économiques de l'OCDE, 2002/2 no 72, p. 199207. CAIRN .INFO. 